\title{
Nutritional Composition of Seeds of the Genus Lupinus
}

\author{
E. STRAKOVÁ ${ }^{1}$, P. SUCHÝ ${ }^{1}$, V. VEČEREK ${ }^{1}$, V. ŠERMAN ${ }^{2}$, N. MAS ${ }^{2}$, M. JUZZL $^{3}$ \\ ${ }^{1}$ University of Veterinary and Pharmaceutical Sciences Brno, Czech Republic \\ ${ }^{2}$ Veterinary Faculty of the University of Zagreb, Croatia \\ ${ }^{3}$ Mendel University of Agriculture and Forestry in Brno, Czech Republic
}

Received April 10, 2006

Accepted June 30, 2006

\begin{abstract}
Straková E., P. Suchý, V. Večerek, V. Šerman, N. Mas, M. Jůzl: Nutritional Composition of Seeds of the Genus Lupinus. Acta Vet. Brno 2006, 75: 489-493.

The aim of this study was to determine and evaluate the chemical composition of the seeds of the genus Lupinus and soybeans. The chemical analyses were carried out in frequently grown lupin varieties in Europe (AMIGA, ANDA, ATU, BORUTA, BUTAN, DIETA, JUNO, KARO, PRIMA, ROSE, SONET and WATT) and two locally grown varieties of soybeans (KORADA and VISION). The contents of individual substances in analysed lupin seeds showed large differences in chemical composition of individual lupin varieties (crude protein: 317.06 - $458.86 \mathrm{~g} \cdot \mathrm{kg}^{-1}$; lipids: 52.15 - 125.76 $\mathrm{g} \cdot \mathrm{kg}^{-1}$; fibre: 101.21 - $154.23 \mathrm{~g} \cdot \mathrm{kg}^{-1}$; non-nitrogenous extractive substances: 285.94 - $436.47 \mathrm{~g} \cdot \mathrm{kg}^{-1}$; starch: 41.31 - $102.65 \mathrm{~g} \cdot \mathrm{kg}^{-1}$; organic matter: 951.75 - $966.24 \mathrm{~g} \cdot \mathrm{kg}^{-1}$; ash: 33.76 - $48.25 \mathrm{~g} \cdot \mathrm{kg}^{-1}$; calcium: 2.29 - $5.10 \mathrm{~g} \cdot \mathrm{kg}^{-1}$; phosphorus: 4.62 - $8.04 \mathrm{~g} \cdot \mathrm{kg}^{-1}$; magnesium: $1.36-2.51 \mathrm{~g} \cdot \mathrm{kg}^{-1}$; acid detergent fibre: 133.13 - $209.25 \mathrm{~g} \cdot \mathrm{kg}^{-1}$ ). Lupin seeds were characterized by high contents of crude protein; in some varieties they significantly exceeded the content of crude protein in soybeans. In contrast to lupine seeds, soybeans contained a significantly higher content of lipids and lower content of fibre including acid detergent fibre. In lupin seeds, a negative correlation coefficient was found between the crude protein and BNLV content $(r=-0.93)$ and between crude protein and starch content $(\mathrm{r}=-0.79)$. A positive correlation $(\mathrm{r}=0.76)$ was found between the starch and BNLV content in lupin seeds. The results of the study provide information not only for growers regarding the choice of individual lupin varieties, but also for breeders who intend to use lupin seeds as suitable components for feed rations and mixtures.
\end{abstract}

Lupins, varieties, chemical composition, seed

At present suitable protein components for feed rations and mixtures for farm animal feeding are searched for. With meat and bone meal being prohibited in farm animal feeding in connection with Bovine Spongiform Encephalopathy (BSE), suitable protein sources for the preparation of vegetable diets are searched for with the objective to secure animal provenance food safety. Apart from soya and soya products, seeds of some varieties of the genus Lupinus appear to be a very perspective source of vegetable protein. In practise we encounter a wide range of diverse varieties mostly derived from the white lupin (Lupinus albus), yellow lupin (L. luteus) and narrow-leaved lupin (L. angustifolius). Experimental studies of Koreleski et al. (1987) or Castanon and Perezlanzac (1990) prove the possibility of a partial replacement of extracted soymeal in diets with a suitable variety of lupin seeds (L. angustifolius, L. albus). RothMaier and Kirchgessner (1993); Lettner and Zollitsch (1995); Ravindran et al. (2002) and other authors recommend lupin seeds as a suitable source of vegetable proteins in diets even for monogastric animals. Lupin seeds have a unique saccharide composition characterized by a low content of starch and high content of non-starch polysaccharides, as stated by VanBarneveld (1999). From this point of view the nutritional value of lupin seeds and their inclusion to farm animal diet is often discussed, asmentioned by Petterson (2000). The seed nutritional value may be significantly increased by hulling, 
as confirmed by Smulikowska et al. (1995). A high content of lupin seeds ( $L$. angustifolius) in diets may worsen production efficiency of feed mixtures due to the absence of some amino acids (methionine), as it was found in hens by Hammershoj and Steenfeldt (2005). It is clear from literary sources that a reasonable use of Lupinus seeds in diets for farm animal feeding requires knowledge and definition of the nutrition composition of the used lupin variety.

The objective of our study was to draw attention to high variability of basic substances in seeds between individual varieties of the genus Lupinus and to compare their contents with those of soybeans.

\section{Materials and Methods}

The analyses were carried out in the laboratory of the Department of Nutrition, Animal Husbandry and Animal Hygiene at the Faculty of Veterinary Hygiene and Ecology of the University of Veterinary and Pharmaceutical Sciences Brno. We have chosen 12 varieties from more than 20 analyzed individual seed varieties of the genus Lupinus (AMIGA, ANDA, ATU, BORUTA, BUTAN, DIETA, JUNO, KARO, PRIMA, ROSE, SONET and WATT). Because these varieties represent the best known and most often grown varieties of lupins in Europe, our sample therefore comprises values of nutrients typical for most lupin varieties. By comparing nutritional values of analysed lupin seeds we used the results of analyses of two varieties of soybeans (KORADA and VISION). Before the analysis itself samples were homogenized and dry matter was determined at $105^{\circ} \mathrm{C}$ to constant weight. Crude protein was calculated from the content $\mathrm{N} \times 6.25 ; \mathrm{N}$ was determined according to Kjehldal on Buchi analyser. The lipid content was determined by a device Fat Analyser ANKOM ${ }^{\mathrm{XT10}}$, crude fibre including acid detergent fibre by a device Fibre Analyser $\mathrm{ANKOM}^{220}$. Ash was determined gravimetrically as a residuum after a sample being incinerated at the temperature of $550{ }^{\circ} \mathrm{C}$ to constant weight under prescribed conditions. $\mathrm{Ca}, \mathrm{P}$ and $\mathrm{Mg}$ elements were determined using chelatometric titration procedure from the extract of an incinerated sample. Organic matter values $(\mathrm{OH}=$ crude protein + lipid + fibre $)$ and non-nitrogenous extractive substances $(\mathrm{BNLV}=$ dry matter - crude protein - lipid - fibre - ash) were established by calculation. For an objective comparison of the obtained results the content of individual content substances was recalculated for $100 \%$ of dry matter. The results of analyses in observed content substances were subject to correlation analysis (STAT PLUS). Significant correlation relations characterized by a correlation coefficient are stated in the results of the study.

\section{Results and Discussion}

It can be seen from the results presented in Table 1 that considerable differences exist in seeds of individual varieties of lupins in the content of individual observed substances.

To make an objective comparison of analysed varieties among them and in relation to soybeans, the values of individual content substances were expressed in $100 \%$ of dry matter because different water content in the seeds of analysed varieties stated in Table 1 would affect their comparison. The contents of individual substances expressed in $100 \%$ of dry matter are in Table 2.

Table 2 shows that lupin seeds contain a large portion of crude protein. The crude protein content of studied varieties ranged rather widely, from $317.06 \mathrm{~g} \cdot \mathrm{kg}^{-1}$ (BORUTA) to $458.86 \mathrm{~g} \cdot \mathrm{kg}^{-1}$ (JUNO). In some varieties of lupin seeds the crude protein content is comparable (AMIGA, KARO) or even higher (DIETA, BUTAN, ANDA, JUNO) than in analysed soybeans. The obtained results are also in accordance with literary sources that similarly point out the large range in the contents of crude protein within the studied varieties, such as RothMaier and Kirchgessner (1993); Lettner and Zollitsch (1995) or Ravindran et al. (2002).

Compared to soybeans, lupin seeds have a significantly lower content of lipids. Their content in the seeds of studied varieties ranged from $52.15 \mathrm{~g} \cdot \mathrm{kg}^{-1}$ (ATU) to $125.76 \mathrm{~g} \cdot \mathrm{kg}^{-1}$ (ANDA). Literary sources unambiguously confirm a lower content of lipids in lupin seeds in comparison with soybeans. The results of lipid analyses differ among individual authors even within the same variety. For instance, in AMIGA variety Lettner and Zollitsch (1995) state the lipid content of $11.3 \%\left(113 \mathrm{~g} \cdot \mathrm{kg}^{-1}\right)$, whereas RothMaier and 
Table 1. Chemical composition of analysed varieties of lupin seeds and varieties of soybeans (KORADA, VISION)

\begin{tabular}{|c|c|c|c|c|c|c|c|}
\hline$(\mathrm{g} / \mathrm{kg})$ & AMIGA & ANDA & ATU & BORUTA & BUTAN & DIETA & JUNO \\
\hline water & 71.50 & 67.30 & 87.20 & 86.30 & 85.60 & 117.80 & 104.30 \\
\hline dry matter & 928.50 & 932.70 & 912.80 & 913.70 & 914.40 & 882.20 & 895.70 \\
\hline crude protein & 329.60 & 409.30 & 320.10 & 289.70 & 347.30 & 320.90 & 411.00 \\
\hline lipid & 80.30 & 117.30 & 47.60 & 53.80 & 93.50 & 84.90 & 49.20 \\
\hline fibre & 110.20 & 94.40 & 133.90 & 136.60 & 103.80 & 114.90 & 127.80 \\
\hline BNLV & 372.80 & 266.70 & 373.70 & 398.80 & 336.90 & 324.60 & 265.40 \\
\hline starch & 85.70 & 56.14 & 71.20 & 83.95 & 81.50 & 78.80 & 37.00 \\
\hline $\mathrm{OH}$ & 892.90 & 887.70 & 875.30 & 878.90 & 881.50 & 845.30 & 853.40 \\
\hline ash & 35.60 & 45.00 & 37.50 & 34.80 & 32.90 & 36.90 & 42.30 \\
\hline $\mathrm{Ca}$ & 3.61 & 4.57 & 3.60 & 3.41 & 4.66 & 3.00 & 3.80 \\
\hline $\mathrm{P}$ & 4.29 & 6.58 & 6.01 & 5.54 & 4.33 & 4.80 & 7.20 \\
\hline $\mathrm{Mg}$ & 1.94 & 2.18 & 1.33 & 2.18 & 1.58 & 1.20 & 2.25 \\
\hline $\mathrm{ADF}$ & 154.30 & 124.17 & 191.00 & 182.30 & 132.40 & 128.30 & 168.11 \\
\hline$(\mathrm{g} / \mathrm{kg})$ & KARO & PRIMA & ROSE & SONET & WATT & KORADA & VISION \\
\hline water & 81.80 & 79.30 & 78.40 & 82.40 & 101.70 & 93.20 & 59.80 \\
\hline dry matter & 918.20 & 920.70 & 921.60 & 917.60 & 898.30 & 906.80 & 940.20 \\
\hline crude protein & 326.30 & 305.70 & 302.50 & 311.60 & 289.80 & 321.10 & 333.90 \\
\hline lipid & 56.20 & 53.70 & 49.10 & 55.70 & 87.10 & 197.20 & 201.60 \\
\hline fibre & 110.40 & 142.00 & 136.90 & 128.50 & 133.70 & 63.80 & 70.70 \\
\hline BNLV & 394.30 & 382.50 & 400.00 & 386.30 & 350.00 & 274.30 & 278.70 \\
\hline starch & 83.00 & 92.90 & 94.60 & 62.00 & 73.68 & 62.00 & 67.70 \\
\hline $\mathrm{OH}$ & 887.20 & 883.90 & 888.50 & 882.10 & 860.60 & 856.40 & 884.90 \\
\hline ash & 31.00 & 36.80 & 33.10 & 35.50 & 37.70 & 50.40 & 55.30 \\
\hline $\mathrm{Ca}$ & 2.10 & 4.00 & 4.01 & 4.50 & 3.20 & 3.19 & 3.60 \\
\hline $\mathrm{P}$ & 4.80 & 5.23 & 4.62 & 5.47 & 5.55 & 7.30 & 8.57 \\
\hline $\mathrm{Mg}$ & 1.88 & 1.94 & 1.46 & 1.34 & 1.94 & 2.18 & 1.94 \\
\hline $\mathrm{ADF}$ & 145.22 & 192.20 & 177.70 & 169.40 & 175.87 & 96.70 & 82.60 \\
\hline
\end{tabular}

Kirchgessner (1993) state the value of $7.6 \%\left(76 \mathrm{~g} \cdot \mathrm{kg}^{-1}\right)$ in the same variety, which corresponds more to our results.

Unlike soybeans lupin seeds contain a relatively high amount of crude fibre, including acid detergent fibre. The crude fibre content in the analysed varieties ranged from $101.21 \mathrm{~g} \cdot \mathrm{kg}^{-1}$ (ANDA) to $154.23 \mathrm{~g} \cdot \mathrm{kg}^{-1}$ (PRIMA), acid detergent fibre from $133.13 \mathrm{~g} \cdot \mathrm{kg}^{-1}$ (ANDA) to $209.25 \mathrm{~g} \cdot \mathrm{kg}^{-1}$ (ATU).

Non-nitrogenous extractive substances (BNLV) represent especially various kinds of saccharides up to non-structural polysaccharides. Their content in seeds of individual lupin varieties ranged from $285.94 \mathrm{~g} \cdot \mathrm{kg}^{-1}$ (ANDA) to $436.47 \mathrm{~g} \cdot \mathrm{kg}^{-1}$ (BORUTA). Table 2 shows that the majority of seeds of analysed lupin varieties have a higher content of BNLV, and therefore also saccharides, than soybeans. The amount of starch in lupin seeds ranged from $41.31 \mathrm{~g} \cdot \mathrm{kg}^{-1}$ (JUNO) to $102.65 \mathrm{~g} \cdot \mathrm{kg}^{-1}$ (ROSE), which is a rather low quantity and presents approximately $20 \%$ of BNLV in average, whereas in cereals starch represents $70 \%$ and more. This fact shows a relatively high presence of non-starch saccharides in lupin seeds. The stated conclusions correspond with V an B arneveld (1999); Ravindran et al. (2002) or Hammershoj and Steenfeldt (2005), who found high contents of non-starch polysaccharides in lupin seeds.

The quantity of organic compounds in the seed is characterized by the content of organic matter. The organic matter content in lupin seeds ranged in a rather narrow range, from 
Table 2. Chemical composition of analysed varieties of lupin seeds and varieties of soybeans (KORADA, VISION) expressed in $100 \%$ of dry matter

\begin{tabular}{|l|r|r|r|r|r|r|r|}
\hline \multicolumn{1}{|c|}{$100 \%$} & \multicolumn{1}{c|}{ AMIGA } & \multicolumn{1}{c|}{ ANDA } & ATU & BORUTA & BUTAN & \multicolumn{1}{c|}{ DIETA } & JUNO \\
\hline crude protein & 354.98 & 438.83 & 350.68 & 317.06 & 379.81 & 363.75 & 458.86 \\
\hline lipid & 86.48 & 125.76 & 52.15 & 58.88 & 102.25 & 96.24 & 54.93 \\
\hline fibre & 118.69 & 101.21 & 146.69 & 149.50 & 113.52 & 130.24 & 142.68 \\
\hline BNLV & 401.51 & 285.94 & 409.40 & 436.47 & 368.44 & 367.94 & 296.30 \\
\hline starch & 92.30 & 60.19 & 78.00 & 91.88 & 89.13 & 89.32 & 41.31 \\
\hline OH & 961.66 & 951.75 & 958.92 & 961.66 & 964.02 & 958.17 & 952.77 \\
\hline ash & 38.34 & 48.25 & 41.08 & 38.09 & 35.98 & 41.83 & 47.23 \\
\hline Ca & 3.89 & 4.90 & 3.94 & 3.73 & 5.10 & 3.40 & 4.24 \\
\hline P & 4.62 & 7.05 & 6.58 & 6.06 & 4.74 & 5.44 & 8.04 \\
\hline Mg & 2.09 & 2.34 & 1.46 & 2.39 & 1.73 & 1.36 & 2.51 \\
\hline ADF & 166.18 & 133.13 & 209.25 & 199.52 & 144.79 & 145.43 & 187.69 \\
\hline \multicolumn{1}{|c|}{$100 \%$} & KARO & PRIMA & ROSE & SONET & WATT & KORADA & VISION \\
\hline crude protein & 355.37 & 332.03 & 328.23 & 339.58 & 322.61 & 354.10 & 355.10 \\
\hline lipid & 61.21 & 58.33 & 53.28 & 60.70 & 96.96 & 217.50 & 214.40 \\
\hline fibre & 120.24 & 154.23 & 148.55 & 140.04 & 148.84 & 70.40 & 75.20 \\
\hline BNLV & 429.43 & 415.44 & 434.03 & 420.99 & 389.62 & 302.50 & 296.40 \\
\hline starch & 90.39 & 100.90 & 102.65 & 67.57 & 82.02 & 68.40 & 72.00 \\
\hline OH & 966.24 & 960.03 & 964.08 & 961.31 & 958.03 & 944.40 & 941.20 \\
\hline ash & 33.76 & 39.97 & 35.92 & 38.69 & 41.97 & 55.60 & 58.80 \\
\hline Ca & 2.29 & 4.34 & 4.35 & 4.90 & 3.56 & 3.52 & 3.83 \\
\hline P & 5.23 & 5.68 & 5.01 & 5.96 & 6.18 & 8.05 & 9.12 \\
\hline Mg & 2.05 & 2.11 & 1.58 & 1.46 & 2.16 & 2.40 & 2.06 \\
\hline ADF & 158.16 & 208.75 & 192.82 & 184.61 & 195.78 & 96.70 & 87.90 \\
\hline
\end{tabular}

$951.75 \mathrm{~g} \cdot \mathrm{kg}^{-1}$ (ANDA) to $966.24 \mathrm{~g} \cdot \mathrm{kg}^{-1}$ (KARO). In lupin seeds organic matter content was slightly higher than in compared soybeans.

The mineral content is characterized by the ash content. In the analysed lupin seeds the ash content ranged from $33.76 \mathrm{~g} \cdot \mathrm{kg}^{-1}$ (KARO) to $48.25 \mathrm{~g} \cdot \mathrm{kg}^{-1}$ (ANDA). The contents of analysed elements in lupin seeds ranged from $2.29 \mathrm{~g} \cdot \mathrm{kg}^{-1}$ (KARO) to $5.10 \mathrm{~g} \cdot \mathrm{kg}^{-1}$ (BUTAN) in calcium, from $4.62 \mathrm{~g} \cdot \mathrm{kg}^{-1}$ (AMIGA) to $8.04 \mathrm{~g} \cdot \mathrm{kg}^{-1}$ (JUNO) in phosphorus and from $1.36 \mathrm{~g} \cdot \mathrm{kg}^{-1}$ (DIETA) to $2.51 \mathrm{~g} \cdot \mathrm{kg}^{-1}$ (JUNO) in magnesium. When comparing the chemical composition of lupin seeds with soybeans, a higher content of ash, and therefore also minerals, was proved in soybeans. In individual analysed elements certain differences were noticed that may be characterized in the majority of analysed lupin varieties by a higher content of calcium and on the contrary a lower content of phosphorus.

Also some relations between contents of substances of lupin seeds may be regarded as interesting. It was established by correlation analysis that the content of BNLV (saccharides) declines with increasing content of crude protein in lupin seeds $(r=-0.93)$. Similarly a high negative correlation $(\mathrm{r}=-0.79)$ was established between the crude protein and starch content. Despite a relatively small amount of starch in lupin seeds, its content was in a positive correlation with the content of BNLV $(r=0.76)$.

In conclusion, our results indicate that lupin seeds of some varieties are very perspective with regard to animal nutrition, especially for their protein feed component. Hence, it is necessary to know the exact relation of lupin variety characteristics with their nutritional composition before their inclusion to feed rations or mixtures. 


\section{Nutriční složení semen rodu Lupinus}

Cílem práce bylo stanovit a ohodnotit chemické složení semen rodu Lupinus a sójových bobů. Chemická analýza byla provedena u nejčastěji v Evropě pěstovaných odrůd rodu $L u$ pinus (AMIGA, ANDA, ATU, BORUTA, BUTAN, DIETA, JUNO, KARO, PRIMA, ROSE, SONET a WATT) a dvou tuzemsky pěstovaných odrůd (KORADA a VISION). Obsahy jednotlivých látek analyzovaných odrůd semen lupin poukazují na velkou rozdílnost v chemickém složení jednotlivých lupinových odrůd (dusíkaté látky: 317,06 - 458,86 g. $\mathrm{kg}^{-1}$; tuk: 52,15 - 125,76 $\mathrm{g} \cdot \mathrm{kg}^{-1}$; vláknina: 101,21 - 154,23 g· kg-1; bezdusíkaté látky výtažkové: 285,94 - 436,47 g. $\mathrm{kg}^{-1}$; škrob: 41,31 - 102,65 g. $\mathrm{kg}^{-1}$; organická hmota: 951,75 - 966,24 g. $\mathrm{kg}^{-1}$; popel: 33,76 - 48,25 $\mathrm{g} \cdot \mathrm{kg}^{-1}$; vápník: $2,29-5,10 \mathrm{~g} \cdot \mathrm{kg}^{-1}$; fosfor: 4,62 - 8,04 g. $\mathrm{kg}^{-1}$; hořčík: 1,36 - 2,51 g. $\mathrm{kg}^{-1}$; acidodetergentní vláknina: 133,13 - 209,25 g. $\mathrm{kg}^{-1}$ ). Lupinová semena byla charakterizována vysokým obsahem dusíkatých látek, u některých odrůd výrazně převyšující obsah dusíkatých látek v sojových bobech. Na rozdíl od lupinových semen obsahovaly sojové boby výrazně vyšší obsah tuku a nižší obsah vlákniny včetně vlákniny acidodetergentní. U lupinových semen byl zjištěn záporný korelační koeficient mezi obsahem dusíkatých látek a obsahem BNLV $(\mathrm{r}=-0,93)$ a mezi obsahem dusíkatých látek a škrobu $(\mathrm{r}=-0,79)$. Kladná korelace $(\mathrm{r}=0,76)$ byla zjištěna mezi obsahem škrobu a BNLV v lupinových semenech. Výsledky práce přinášejí podklady nejen pro pěstitele $\mathrm{z}$ hlediska atraktivnosti pěstování jednotlivých odrůd lupin, ale i pro chovatele, při využití lupinových semen jako vhodné komponenty do krmných dávek a krmných směsí.

\section{Acknowledgement}

This work was part of the Research Plan of the Ministry of Education, Youth, and Physical Training of the Czech Republic No. MSM6215712402 "Veterinary aspects of food safety and quality".

\section{References}

CASTANON JIR, PEREZLANZAC J 1990: Substitution of Fixed Amounts of Soyabean Meal for Field Beans (Vicia faba), Sweet Lupins (Lupinus albus), Cull Peas (Pisum sativum) and Vetches (Vicia sativa) in Diets for High-Performance Laying Leghorn Hens. Brit Poult Sci 31: 173-180

HAMMERSHOJ M, STEENFELDT S 2005: Effects of Blue Lupin (Lupinus angustifolius) in Organic Layer Diets and Supplementation with Foraging Material on Egg Production and Some Egg Quality Parameters. Poult Sci 84: 723-733

KORELESKI J, RYS R, KUBICZ M 1987: Seeds of New Domestic Varieties of Lupin, Pea and Soyabean in Diets for Table Chickens and Rats. Rocz Nauk Zoot 25: 221-244

LETTNER F, ZOLLITSCH W 1995: Lupins in Broiler Feeds. Forderungsdienst 43: 285- 288

PETTERSON DS 2000: The Use of Lupins in Feeding Systems- Review. Asian Australas J Anim Sci 13: $861-882$

RAVINDRAN V, TABE LM, MOLVIG, L, HIGGINS, TJV, BRYDEN WL 2002: Nutritional Evaluation of Transgenic High-Methionine Lupins (Lupinus angustifolius L.) for Broiler Chickens. J Sci Food Agric 82: 2 80-285

ROTHMAIER DA, KIRCHGESSNER M 1993: Composition and Nutritional Value of Various White and Yellow Lupin Varieties (Lupinus albus L. and Lupinus luteus L.) for Pigs and Poultry. Agribiol Res 46: 218-228

SMULIKOWSKA S, WASILEWKO J, MIECZKOWSKA A 1995: A Note on the Chemical Composition of the Cotyledons and Seed Coat of Three Species of Sweet Lupin. J Anim Feed Sci 4: 69-76

VAN BARNEVELD RJ 1999: Understanding the Nutritional Chemistry of Lupin (Lupinus spp.) Seed to Improve Livestock Production Efficiency. Nutr Res Rev 12: 203-230 